\title{
The concession Groningen: A lawyer's view
}

\section{B.G. Taverne}

Former Professor of Petroleum Law and Policies at the Delft University of Technology

Manuscript received: 30 May 1999; accepted in revised form: 3 Aug 2000

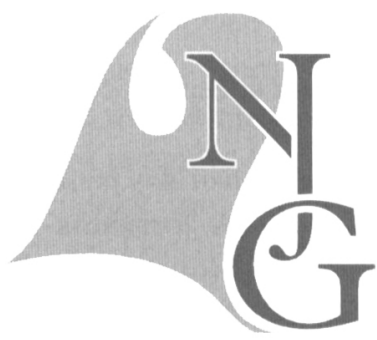

\begin{abstract}
The discovery in 1959 of natural gas in a well drilled by the Nederlandse Aardolie Maatschappij (NAM) near Hoogezand, Gemeente Slochteren, a town in the Province of Groningen, led to the development and establishment of major natural gas production in the Netherlands. This important industrial development could not have started and the necessary investments would not have been made by the industry, if not in accordance with the then applicable Napoleonic Mining Law of 1810 a concession had been applied for and granted allowing to exploit this discovery. From this point of view, admittedly a lawyer's view, the award of the concession, which was named Groningen, should be considered to be the actual starting point for the aforesaid development.

On 1 July 1961 NAM submitted its application for a concession based on its Slochteren discovery and with this submission the negotiations started between the Netherlands government on the one side and NAM and its two shareholders, viz. Shell and Exxon, on the other side, on the terms and conditions to be incorporated in the applied for concession. On the government's side attention was focused on two aspects: how to integrate the natural gas discovered into the economy of the country and how to involve the State in the production and disposal thereof. From the outset the government intended, that the State's interests should be represented by the Staatsmijnen in Limburg (State Mines) in order to give this coal mining enterprise a future outside and independent from its ailing coal mining business in the Province of Limburg. To this end the government arranged for State Mines to enter into a maatschap (partnership) with NAM. In this partnership State Mines would get a $40 \%$ participating interest, leaving $60 \%$ for NAM. The concession would be granted to NAM, but the latter would be obliged to produce the natural gas reserves contained within the concession for the account and responsibility of the partnership. The partnership would be managed by State Mines with a $50 \%$ voting right and by NAM's two shareholders each with a $25 \%$ voting right.

In the deed of concession, which was granted on 30 May 1963, it is stipulated, that any natural gas not needed by the concessionaire for its own operations should be sold to a corporation to be designated by the Minister and the articles of association of which would require the latter's approval. This corporation, named the NV Nederlandse Gasunie (the Gasunie), was established on 6 April 1963. Its shareholders were (and still are) State Mines (now Energie Beheer Nederland (EBN)) with a $40 \%$ shareholding interest, the two shareholders of NAM, each with a $25 \%$ interest, and the State itself with a $10 \%$ interest. The Gasunie is allowed to realise from its business of buying, transporting and selling natural gas an after tax profit of NGL 80 million per year. Any surplus revenues are transferred to NAM (the transfer sum) in payment of the gas delivered by NAM.

The concession area comprises about 2,970 square $\mathrm{km}$, covering the territory of the Province of Groningen and the territorial waters adjacent to the Province. The concession area includes part of the Waddenzee, an area in respect of which special environmental/zoning rules and regulations are in force. As a matter of fact any exploitation of the gas reserves situated in that area is ruled out, at least for the foreseeable future.

The concession area also includes an area described as the Common Area in the Supplementary Eems / Dollard Agreement of 14 May 1962. Under the terms of this Agreement natural gas produced from the gas reserves situated in the Common Area had to be shared with German concessionaires. NAM was appointed the operator for implementing the provisions of the Agreement.

A certain varying amount of subsidence is experienced throughout the concession area. In this matter the partnership agreed to compensate, up to a certain financial limit, third parties which incurred costs or suffered damage in connection with said subsidence.
\end{abstract}

Keywords: concession Groningen conditions, State Mines/EBN, NAM and its Shareholders, the Partnership, Government, Gasunie, Waddenzee, Common Area, subsidence 


\section{Introduction}

On 5 August 1959 a news item appearing in Het Vrije Volk, at the time the newspaper with the largest circulation in the Netherlands, informed the Dutch public that gas had been discovered in a well drilled by the Nederlandse Aardolie Maatschappij (NAM) near Slochteren, a town in the Province of Groningen.

This discovery prompted NAM, after some further investigations, to apply on 1 July 1961 for an exploitation concession in accordance with the then existing mining legislation. This application led to the start of negotiations between the Netherlands government on the one side and NAM and its two shareholders, viz. Shell and Exxon, on the other side, in order to establish the terms and conditions under which the desired concession should be granted.

On 11 July 1962, the government presented to Parliament its Natural Gas Policy Paper, setting out its views on how to utilize the natural gas reserves for the benefit of the economy of the country as well as for securing for the Staatsmijnen in Limburg (State Mines) a future outside and independent from its ailing coal mining business in the Province of Limburg.

On 30 May 1963, after about two years of negotiations, the applied for concession was finally granted. The concession was named Groningen.

This important event signified, that between government and the oil companies involved agreement was reached on the questions and issues that were raised by the unexpected discovery of such important gas reserves. Seen in this light, so to speak from a lawyer's point of view, it could be said with some justification, that the award of the concession Groningen rather than the discovery of the natural gas should be considered to be the actual starting point of the development of a natural gas industry in the Netherlands.

From a legal point of view, the concession is important and deserves close scrutiny because it authorizes and regulates the exploitation of the largest onshore gas reserves in Europe and it provides for the participation of the State in the production and disposal of these reserves. The latter feature continued a tradition of state participation and intervention in the exploitation of natural resources (coal and salt) in the Netherlands, but outside this country state participation in petroleum concessions or petroleum agreements was still something of a novelty and ahead of its time. Furthermore, as of 1971 , the concessionaire agreed to pay an excess revenue tax, another feature this time of a fiscal nature that in 1971 was ahead of its time.

Apart from this, there are still other reasons why the concession Groningen deserves discussion. These other reasons are all connected in one form or another with the concession area.

Firstly, the concession area includes part of the Waddenzee, an area in respect of which special environmental/zoning rules and regulations are in force. As a matter of fact, any exploitation of the gas reserves situated in that area is ruled out, at least for the foreseeable future.

Secondly, the concession area includes along the border with Germany a contested area, where operations are subject to the provisions of a boundary treaty with Germany.

Thirdly, the concession area has for many years experienced some minor but wide-spread subsidence caused by the compaction of the reservoir rock from which the natural gas is extracted. This physical phenomenon has raised the legal question of who is liable to pay for the measures needed either to repair any damage done or to prevent any damage occurring. Subsidence is also expected to occur in the said Waddenzee and this expectation forms a major obstacle for getting permission to extract natural gas from beneath that area.

\section{Legal background}

For a proper understanding of the concession Groningen and its conditions and of the manner, in which these conditions have been established, it is necessary to sketch briefly the Netherlands mining regime prevailing at the time.

This mining regime comprised:

(a) the French Napoleonic Mining Law of 21 April 1810 , which had become effective in the Netherlands when the country formed part of the French Napoleonic empire (Imperial Decree of 8 November 1810);

(b) the Mining Law of 27 April 1904 (referred to as the Mining Law of 1903). This Mining Law inter alia authorizes the government to make and issue from time to time regulations concerning safety and health matters, working conditions and methods; and

(c) the terms and conditions of the four petroleum concessions, that some years earlier had been granted to NAM.

Re (a). The Mining Law of 21 April 1810, in the form as it was when the concession Groningen was applied for and awarded, i.e. before its amendment in 1988, is hereinafter simply referred to as the Mining Law. This Law contains a listing of the mineral substances, in respect of which its provisions apply. Among the minerals listed is 'bitumen'. Oil and natural gas as such 
are not included in the list. These hydrocarbons cannot be considered to be covered by or comprised in the expression 'bitumen', in the way this expression was used and understood by the makers of the Mining Law. Nevertheless, oil and natural gas have never been added to the list, even not, when much later the first application for a concession for oil and natural gas was made (viz. the application which led to the award of the concession Schoonebeek on 3 May 1948). The right to explore for the listed substances is reserved to the landowner or to the person who gets his permission. In the event that the landowner refuses to give his permission, a special authorization of the government may be obtained. This freedom to explore has from time to time been restricted by special laws for specific periods, but at the time of the drilling of the Slochteren-well, no such restriction was in force. For the exploitation of any of the listed minerals, that is discovered an exclusive and specific concession is required to be granted by Royal Decree and after the Raad van State (State Council) has been consulted and given its advice. Any person, including of course the person, who actually has made the discovery (the finder), may apply for such a concession, provided always that the applicant is capable and has the means, financial and otherwise, to undertake and manage the exploitation and to pay the compensation required to be paid by the concessionaire (among which the compensation to be paid to the finder if the concession had not been awarded to him). As a matter of fact, the Mining Law allows the government every freedom and authority to award concessions to whomever it wants and to formulate and stipulate the terms and conditions to be attached thereto. The Mining Law itself imposes only a few obligations on the concessionaire, most obligations are found in the concession concerned and are the outcome of freely held negotiations between government and applicant. The government's discretionary power is not restricted in the sense, that it can only be exercised subject to any form of parliamentary control or supervision over concession matters.

In the case of the Slochteren discovery NAM could not claim a right to be awarded a concession. As a matter of fact, the government could have given the applied for concession to State Mines, a possibility, that during the negotiations was briefly mentioned by the government. If this would have happened NAM could only have claimed a finder's fee, payable by State Mines. Apart from the obligations set out in the Law and/or in the concession, the concessionaire is always subject to the rules and regulations, that from time to time are issued under the Mining Law 1903.
Re (c). When NAM submitted its application for a concession with regard to its Slochteren discovery, the company had previously already been granted four other concessions for oil and natural gas, viz. the concession Schoonebeek (Royal Decree of 3 May 1948); the concession Tubbergen (Royal Decree of 11 March 1953); the concession Rijswijk (Royal Decree of 3 January 1955) and the concession Rossum - De Lutte (Royal Decree of 12 May 1961). It follows that the terms and conditions agreed with respect to these earlier concessions were the only precedents available. In accordance with these precedents, the non-financial terms and conditions were set out in a detailed form in the concession itself, whereas the financial conditions were spelled out in a special financial agreement. The draft of this special agreement was attached to the concession document and the minister was authorized to conclude with the concessionaire an agreement that was identical to the draft.

\section{The making of the concession Groningen}

Soon after the negotiations started, it became clear to all parties concerned, that a major natural gas deposit had been discovered. The first estimates of the gas reserves made in 1960 amounted to 60 billion cubic meters, although already in October of that year a figure of 300 billion cubic meters was circulating in the press. Although not obliged under the Mining Law to do so, the government considered it prudent to involve, inform and consult Parliament about its policy and strategy regarding the exploitation of the newly discovered gas reserves and about the progress of the negotiations with NAM and its shareholder concerning the terms to be incorporated in the applied for concession. The involvement of Parliament was considered essential because it became soon apparent, that important gas reserves had been found and that their exploitation could present a solution for the deteriorating economic and financial position of State Mines. Not surprisingly, the suggestion was made, that the best solution would be to award the concession applied for by NAM to State Mines (see above).

On 11 July 1962, the government presented to parliament its Nota inzake aardgas, a Natural Gas Policy Paper, in which the government outlined its policy objectives with respect to the natural gas reserves discovered by NAM. Attention was focused on two aspects: how to integrate the natural gas into the economy of the country and how to involve the State in the exploitation and disposal of the reserves. Remarkably, measures to increase the government take (as compared with the financial conditions agreed with re- 
spect to the earlier concessions) were not envisaged or considered.

The stated government policy was shaped by the following events, facts and assumptions:

1. In the second half of 1961 the cost of State Mines' coal production exceeded the price for which this production could be sold. The financial and economic position of State Mines was quickly deteriorating.

2. Proved reserves (P90-reserves) of 150 billion cubic meters and probable reserves (P50 reserves) of 400 billion cubic meters; and

3. The findings of the Tweede Peelcommissie. This advisory Committee had been established in 1952 in order to study and investigate the economic feasibility of starting one or more coal mines in the Peel area. The Committee finally submitted its report in 1962. Highlights of the report: - between 1975 and 2000 nuclear electricity would become competitive with fossil electricity; - oil and natural gas would be capable to satisfy any increase in the demand for energy; - there was no scope to expand the capacity of the coal mines; moreover, continued exploitation of the coal mines could only be justified for social reasons and for the benefit of the country's external trade account.

On the basis of the above information and in particular taking into account the Peel Committee's expectation regarding the breakthrough of nuclear electricity before the year 2000, the government proposed in its Natural Gas Paper that:

1. The natural gas reserves estimated at 400 billion cubic meters should be produced before the year 2000 , i.e. before nuclear electricity would be capable to replace fossil electricity;

2. During this 30 year period natural gas should take for its account $30 \%$ of the country's demand for energy and should by priority be used in the domestic sector (for central heating, cooking, hot water);

3. To use for these household purposes 200 billion cubic meters, which would leave 200 billion cubic meters for export.

With hindsight, it could be said, that the Natural Gas Paper as well as the report of the Peel Committee were based on the wrong assumptions. The Natural Gas Paper was wrong about the size of the natural gas reserves, the latter proved to be many times larger. The Peel Committee was wrong with respect to the market penetration of nuclear electricity. Still it can not be said that these wrong assumptions have deterred or undermined the development of the natural gas activities in the country.
State participation in the exploitation of the concession

As mentioned before, the government tried to secure for State Mines a future outside the ailing coal mining industry in Limburg. Participation in the exploitation of the newly discovered natural gas reserves appeared to provide an answer. After protracted negotiations it was agreed to set up a maatschap (partnership) between State Mines and NAM, the intended concessionaire, in which State Mines would take a $40 \%$ participating interest and NAM the remaining $60 \%$. Within this framework, NAM would be granted the concession, become the sole concessionaire and would be obliged to operate the concession for the account of the partnership and in accordance with the latter's instructions. The management of the partnership was entrusted to State Mines with a $50 \%$ voting right and to the two shareholders of NAM, each with a $25 \%$ voting right. In the interest of confidentiality (at the time, as has been remarked before, state participation in oil concessions was, at least outside the Netherlands, still a novelty and a feature that was generally resisted by the private international oil industry), the finally agreed modalities of state participation were not laid down in the concession itself. In the latter it is only stipulated that the concessionaire should undertake the exploitation of natural gas in accordance with the terms of an agreement of cooperation between and among the concessionaire, his shareholders and State Mines and that this agreement needed the approval of the minister. However in the financial agreement attached to the concession a reference can be found to the $40 \%$ participating interest that had been assigned to State Mines (see below).

State participation in the disposal of the natural gas production

The other issue to be dealt with concerned the disposal of the natural gas, that would be produced by NAM (for the account of the partnership). Under the terms and conditions of the four earlier concessions, any natural gas produced, that the concessionaire did not need for his own operations, had to be sold against a reasonable price to the State, for which purpose an agreement between State and the concessionaire should be concluded. The Minister of Economic Affairs was authorised to decide, that the natural gas, that had to be delivered to the State, wholly or partly should be sold to a third party to be designated by the Minister. The first third party-buyer designated by the Minister under these terms had been a government entity, the Rijksdienst Gasvoorziening, established within the Ministry of Economic Affairs. In 
1957 the Rijksdienst was replaced by the Staatsgasbedrijf.

With respect to the intended concession, a different set-up was agreed in view of the fact that much larger quantities appeared to be involved. It was agreed, that the natural gas produced from the concession should be sold to a corporation named the $N V$ Nederlandse Gasunie (Gasunie). The said corporation was established on 6 April 1963, just before the concession itself was granted to NAM. The shareholders of the Gasunie were (and still are) State Mines (later replaced by Energie Beheer Nederland (EBN)) with a $40 \%$ shareholding interest, the two shareholders of NAM, each with a $25 \%$ interest, and the State itself with a $10 \%$ interest.

Gasunie took over the activities of the aforementioned Staatsgasbedrijf. The Gasunie was set-up for the purpose of buying natural gas (from NAM as well as from any other producer in the Netherlands), transporting (after conditioning) any gas so bought and selling the same on the domestic market or abroad. The Gasunie pays NAM a transfer sum for natural gas delivered by NAM. This sum represents the revenues obtained by the Gasunie in selling all natural gas bought by the Gasunie from any producer in the Netherlands including NAM less the money paid to the producers other than NAM, less the costs incurred by Gasunie with respect to the treatment, handling and transport of the gas so bought to the respective points of offtake, and less such an amount as yields the Gasunie an after tax profit of NGL 80 million per year. This last figure represents a $20 \%$ (after tax) return per year on the initial investment in the business of the Gasunie. All those details are not found or indicated in the deed of concession. In the latter it is only stipulated that any surplus natural gas should be sold to a corporation to be designated by the Minister and that the articles of association of that corporation have to be approved by the latter.

Other non-financial conditions (as included in the concession)

The non-financial conditions other than state participation in production and disposal were more or less the same as those stipulated in NAM's four earlier concessions. It is stipulated, that the concessionaire must conduct his operations and utilize his works in such a manner, that as far as possible, no damage is caused to properties situated within the concession area or in areas adjacent thereto. Furthermore, the concessionaire must avoid harmful methods of working, make payments to the landowners, submit information and reports, and keep records as specified.
The concession also stipulated, that the majority of the managing directors of NAM should have the Netherlands nationality and it gave the government the option to appoint a government representative for the purpose of supervising the activities of the concessionaire. The government representative was given the powers of access to the books and records of the concessionaire, to all offices and buildings and to the concession area as well as to the meetings of the shareholders and/or directors of the concessionaire. This option, that was also part of the conditions attached to the four earlier concessions, reflected the government's interest in participating in the exploitation of natural resources, and continued the long tradition of state participation in the exploitation of various coal and salt concessions.

In 1975,1976 and in 1983 the non-financial conditions were expanded and became more detailed, mainly in respect of the manner in which the concessionaire must conduct his operations. The non-financial conditions of the four earlier concessions were revised in a similar manner. The amendments were effectuated by Royal Decree.

\section{The financial conditions (as included in the financial agreement)}

During the negotiations, the government was focused on the need to secure the future of the State Mines in the overall context of the introduction of natural gas in the domestic market. With respect to the financial conditions to be incorporated in the financial agreement, the government saw no reason to deviate from the system of financial contributions, that were agreed with respect to the four earlier concessions granted to NAM. In essence, this meant that apart from the corporation tax, the concessionaire was only expected to pay a $10 \%$ net profit share. No royalty was payable.

A strong link with these earlier concessions was maintained. For the purpose of calculating the $10 \%$ net profit share (i.e. profit after tax) the financial results of all five concessions, after deduction of the corporation tax payable in respect thereof, are aggregated. As far as the financial results of the concession Groningen are concerned before these are aggregated with the results of the other concessions they are reduced by $40 \%$ in order to account for the $40 \%$ state participation in said concession. In combination with the corporation tax as levied at the then existing rate, the $10 \%$ net profit share, which payment itself is treated as a deductible item in calculating taxable income, resulted in a 50/50 gross profit sharing. This result was not a coincidence. The $50 / 50$ gross profit 
sharing was known from the Middle East Gulf region, where this principle in December 1950 had been introduced by the government of Saudi Arabia in respect of its traditional concession and with which principle Shell and Exxon, the shareholders of NAM, were familiar.

However, the 50/50 arrangement as described above lasted for less than 10 years. In 1971 an additional financial agreement was concluded exclusively related to the type of natural gas that was produced from the Slochteren reservoirs. Said gas referred to as Slochteren-gas was a low-calorific type of natural gas and served as the standard quality gas. The said additional financial agreement provided for an overall sharing in a $75 / 25$ proportion in favour of the State of the concessionaire's incremental sales revenues. The latter were defined as revenues corresponding to that part of the sales price (for standard quality gas) exceeding 6 cents per cubic meter. The 6 cents per cubic meter was indexed at one-third of the development of the oil price or one third of the rate of inflation, whichever turned out to be lowest. The standard financial arrangement, consisting of a combination of a $10 \%$ net profit share plus corporation tax (resulting in a more or less a $50 / 50$ sharing of the incremental revenues) was maintained. Make-up payments had to be made by the concessionaire to cover the difference. On account of state participation, $40 \%$ of the sales revenues already accrued to the state participant. To this basic share should then be added $75 \%$ of the concessionaire's $60 \%$ share, resulting in a combined state / state participant share of $85 \%$ of incremental revenues, leaving the concessionaire a $15 \%$ share thereof. The new financial arrangement only concerned revenues obtained by selling standard quality gas in the Netherlands. Sales revenues obtained from the export of standard quality gas were excluded. This changed, when with effect from 1 January 1975, in the light of the increases of the international price of exported oil, the government decided to revise the financial arrangement. Revenues from export sales became included in the overall sharing of the incremental revenues and the latter were redefined on the basis of dividing the sales price into three successive price intervals or sectors instead of two as was previously agreed. The second price sector started at 5.5 cents per cubic meter and ended at 8.5 cents per cubic meter, at which price the third sector started. Both reference prices were indexed in the manner as previously agreed. Concessionaire's revenues falling into the second price sector and those falling into the third sector had to be shared in an overall manner, by means of making a make-up payment, in a $75 / 25$ and $85 / 15$ proportion respectively.

\section{Some legal complexities involving the conces- sion area}

The concession area comprises about 2,970 square $\mathrm{km}$, covering the territory of the Province of Groningen and the territorial waters adjacent to the Province.

Legal complexities involving the concession area arise on three counts.

Firstly, the concession area includes part of the Waddenzee, an area in respect of which special environmental/zoning rules and regulations are in force. This circumstance proved to have consequences for the freedom of the concessionaire to conduct petroleum operations in this part of his concession area. While no production facilities may be brought into the area, it is also uncertain if ever any extraction of natural gas from beneath the area will be allowed in view of the subsidence, that is expected to occur as a result thereof.

Secondly, the eastern part of the concession area includes a contested area. This area, coinciding with the estuary of the river Ems, is bounded by the borders as claimed by the Netherlands and Germany respectively. In order to allow the exploitation of the mineral resources, that were expected to be present in the subsoil of the contested area, the two States made an special agreement (the Supplementary Agreement of 14 May 1962) supplementary to the earlier Eems/Dollard Agreement of 8 April 1960. The Supplementary Agreement defines the said contested area as 'the Common Area'. The totality of the Common Area is part of and comprised in the Groningen concession area, but the same applies with respect to two German concessions granted in that area. To separate the conflicting jurisdictions the Common Area is divided by a line. All oil and natural gas that could be produced over time from the volume of oil or natural gas present in situ underneath the Common Area prior to the start of production, had to be shared in equal proportions by and between the concessionaires on both sides. The Netherlands concessionaire, in this case NAM, was appointed as the operator and was made responsible for delivering to the German concessionaires the quantities of natural gas to which these concessionaires were entitled.

In the concession, reference is made to the said Supplementary Agreement and in order to implement its provisions it is stipulated in the concession, that the concessionaire may only exercise his rights under the concession in accordance with the provisions of the Supplementary Agreement. The gas deliveries to the German concessionaires have stopped. It has been agreed between the parties and the two 
governments, that a volume of 20 billion cubic meters has been over-delivered, for which the Netherlands concessionaire will be compensated.

Thirdly, there are the legal and technical problems caused by the subsidence of the area resulting from the gas extraction. As a result of the subsidence, third parties were and still are forced to take measures aimed at preventing, that the subsidence would cause damage to properties or to take measures for repairing any such damage, that could not reasonably be prevented. The question arose of who was liable for paying the cost incurred by these third parties in taking these measures. Neither two Mining Laws nor the concession contains provisions with regard to the liability of the concessionaire for paying compensation, if and when his operations cause damage or losses to third parties.

It follows that the matter of liability must be treated within the context of civil law. In the case of the concession Groningen third parties, which suffered losses as a result of the subsidence occurring in the area, have demanded from the concessionaire payment of an adequate compensation. Without admitting or acknowledging any responsibility or liability and on a voluntary basis, NAM and its partner EBN agreed to compensate, up to a certain financial limit, third parties that have submitted or will in the future submit claims in connection with the subsidence.

\section{The grant of the concession Groningen}

With the establishment of the Nederlandse Gasunie on 6 April 1963, and the grant of the concession named Groningen to NAM on 30 May 1963, the negotiations and parliamentary discussions came to an end. A new era in the economic development of the Netherlands could begin.
On 25 July 1963, the exploitation drilling campaign started. At that moment, the gas reserves were estimated at 500 billion cubic meters, but it remained unclear whether proved (P90) or probable (P50) reserves were indicated. On 23 October of the same year NAM convened a press conference and announced, that on the basis of the result of the drilling work the proved gas reserves were estimated to amount to 1,100 billion cubic meters, about three times higher than the figure, on which the Government Natural Gas Paper had been based.

\section{References}

Algemene Energieraad, 1982. Wat doen we met ons aardgas? Staatsuitgeverij, Den Haag.

Bakker, V., Salverda, F., 1983. De Jacht op ons Aardgas. VN Vrij Nederland, 15 januari 1983.

Breij, B., 1991. De Mijnen Gingen Open, de Mijnen Gingen Dicht. ICOB cv, Alphen aan den Rijn.

Kielich, W., 1988. Ondergronds Rijk, 25 Jaar Gasunie en Aardgas. Uniepers bv, Amsterdam, 1988.

Ministerie van Economische Zaken, Directoraat-Generaal voor Energie, 1990. Even Stilstaan bij Vooruitgang, Directoraat voor Energie, Den Haag.

Nederlandse Aardolie Maatschappij b.v., 1984. Gasaardig. Nederlandse Aardolie Maatschappij, Assen.

Taverne, B.G., 1992. Van Kolenwinning tot Energievoorziening: 100-jaar Nederlands Overheidsbeleid. Eeuwboek van de Mijnbouwkundige Vereeniging te Delft, Delft, 1992.

Taverne, B.G., 1993. Beginselen en Voorbeelden van Regelgeving en Beleid ten aanzien van de Opsporing en Winning van Aardolie en Aardgas. Delftse Universitaire Pers.

Taverne, B.G., 1997. Leven tussen de Regels; Over Zaken, die de Petroleumindustrie beroeren. Uittreerede, Delftse Universitaire Pers / 1997.

Taverne, B.G., 2000. Petroleum, Industry and Governments. An Introduction to Petroleum Regulation, Economics and Government Policies. Kluwer Law International, The Hague - London - Boston. 